Marquette University

e-Publications@Marquette

Theology Faculty Research and Publications

Theology, Department of

5-1-2011

Continuity and Development in Roman Catholic Ecclesiology

Susan K. Wood

Marquette University, susan.wood@marquette.edu

Accepted version. Ecclesiology, Vol. 7, No. 2 (May 2011), DOI: (C 2011 Brill Academic Publishers. Used with permission. 
NOT THE PUBLISHED VERSION; this is the author's final, peer-reviewed manuscript. The published version may be accessed by following the link in the citation at the bottom of the page.

\title{
Continuity and Development in Roman Catholic Ecclesiology*
}

\author{
Susan K. Wood \\ Department of Theology, Marquette University \\ Milwaukee, WI
}

\begin{abstract}
An overview of the conceptualizations of the Catholic Church from the theology of Bellarmine to contemporary understanding of the church as communion shows both continuity and development from one concept to the next rather than an abrupt change to a new model that discards the model preceding it. This essay examines the church as perfect society, church as mystical body, church as sacrament, church as people of God, and church as communion, demonstrating that the various conceptualizations represent development, balance, correction, and a deeper penetration in the understanding and articulation of the prior conceptualizations. The church as body of Christ develops the spiritual and Christological dimension of the church as society. The church as sacrament offers a way of differentiating between Christ and the church while at the same time retaining the close correlation between the two. The church as people of God introduces historical consciousness into the definition of the church. The church as communion synthesizes the strong sacramental and spiritual identity of the church with its organizational structure.
\end{abstract}


NOT THE PUBLISHED VERSION; this is the author's final, peer-reviewed manuscript. The published version may be accessed by following the link in the citation at the bottom of the page.

To speak of a 'Catholic Ecclesiology' is a fairly recent phenomenon if one takes the long view of things. 'Ecclesiology' as that sub-discipline of theology that deals with the nature and mission of the church has only existed in the technical sense since the fourteenth century. ${ }^{1}$ Certainly, elements of ecclesiology, such as the teaching on the unity of the church or an articulation of the idea of apostolic succession, developed during the patristic period in response to the challenges presented by heresy, schism, and persecution. ${ }^{2}$ As the structures of the church developed slowly over time, so too did theological reflection on the nature and mission of the church. Even as early as the New Testament, we witness a development of church structure from the Pauline Epistles to the Pastoral Epistles. An older charismatic structure of the church under the leadership of apostles, prophets, and teachers gradually gave way to the presbyter/bishop and eventually to the more formal structure of a monarchical episcopate, the rule of a church by a single bishop assisted by a presbyterate. ${ }^{3}$ Church structures developed over time in response to practical needs (patriarchates and episcopal conferences address the local needs of a segment of the church often defined culturally, linguistically, or nationally); in response to political forces (the lay investiture controversy stressed the independence of the church vis-àvis emperors and monarchs); and, finally, in response to theological reflection (papal primacy is arguably a theological interpretation of the pope as successor to Peter and a reflection on Peter's role in the New Testament). Therefore, to speak of Roman Catholic ecclesiology is to speak of a developing concept. Various conceptualizations of the church are in a dialogical, and sometimes admittedly polemical, relationship to other ecclesial bodies or cultural influences.

Nevertheless, there is continuity as well as change in both the structures and theology of the church. Some structures are considered as possessing the force of divine law (de jure divino), while others were viewed as contingent developments subject to change (de jure humano). For example, Vatican II teaches that 'the bishops have by divine institution taken the place of the apostles as pastors of the church. ${ }^{4}$ In Roman Catholic ecclesiology a bishop standing in apostolic succession is essential to the definition of a church, whether that be the definition of the smallest entity that can be considered a church within Roman Catholicism, the particular church administratively

Ecclesiology, Vol 7, No. 2 (May 2011): pg. 147-172. DOI. This article is @ Brill Academic Publishers and permission has been granted for this version to appear in e-Publications@Marquette. Brill Academic Publishers does not grant permission for this article to be further copied/distributed or hosted elsewhere without the express permission from Brill Academic Publishers. 
identified as a diocese, ${ }^{5}$ or in the mutual recognition of churches within ecumenical relations. ${ }^{6}$

In what follows I will present Catholic ecclesiology by tracing continuity and change through five major conceptualizations of the church: church as perfect society, church as body of Christ, church as sacrament, church as people of God, and church as communion. This approach also presents a historical trajectory beginning with the postTridentine theology of Robert Bellarmine and continuing through the pre-Vatican II theology of Pius XII and the theology introduced by the Second Vatican Council up to the Synod of Bishops in 1985 and into contemporary ecclesiology today. It also respects the teaching of the first chapter of the Dogmatic Constitution on the Church, the belief that the church is a mystery whose reality can only be approached through a variety of images.

\section{Church as Perfect Society}

After the Reformation, Roman Catholic ecclesiology was shaped by the polemical climate of that era. In many respects, Catholic selfunderstanding was contrastive, defined over against what it understood the Protestant position to be. Counter-Reformation Catholic theologians understood the Lutheran teaching to be that the true church was the society of the saints whose membership was known only to God - that is, they understood the Reformers as teaching a doctrine of the invisibility of the church. ${ }^{7}$ Bellarmine (15421621), for example, gave an account of the Church as a perfect society defined institutionally. By 'perfect society' Bellarmine meant that the church contains all the necessary elements to accomplish the end for which it was intended, namely the salvation of all humanity. In response to a Protestant critique of the visible, hierarchical structure of the Catholic Church, Bellarmine stressed precisely its visible elements, defining the one true church as: 'the community of men brought together by the profession of the same Christian faith and conjoined in the communion of the same sacraments, under the government of the legitimate pastors and especially the one vicar of Christ on earth, the Roman pontiff. ${ }^{8}$ Here the church is not just identified by faith, but by the profession of faith, which is something visible, similar to legitimate pastors hierarchically ordered in the church as well as communion in

Ecclesiology, Vol 7, No. 2 (May 2011): pg. 147-172. DOI. This article is @ Brill Academic Publishers and permission has been granted for this version to appear in e-Publications@Marquette. Brill Academic Publishers does not grant permission for this article to be further copied/distributed or hosted elsewhere without the express permission from Brill Academic Publishers. 
the sacraments, understood as outward signs of grace. Bellarmine concludes: 'And it is as visible as the Kingdom of France or the Republic of Venice. ${ }^{\prime 9}$ To be fair to Bellarmine, he distinguished between the body of the church and its soul, identified as the Holy Spirit, but his famous definition reinforced a notion of the church as an institutional society.

\section{Church as Mystical Body of Christ}

The institutional, visible, and hierarchical emphasis of the postTridentine ecclesiology found a balance with the publication of Pius XII's encyclical Mystici Corpori, in 1943, which retrieved the biblical and patristic image of the body of Christ. Even though it tempered the institutional emphasis of Bellarmine's theology through the retrieval of biblical imagery, it did not disregard it, stating that although it was possible for Christ to impart graces to mankind directly, 'He willed to do so only through a visible Church made up of men [sic], so that through her all might cooperate with Him in dispensing the graces of Redemption. ${ }^{\prime 10}$ Pius XII compares the use of the church to the Incarnate Word's use of a human body in his work of redemption. He continues the polemic against an invisible church when he remarks,

But it is not enough that the Body of the Church should be an unbroken unity; it must also be something definite and perceptible to the senses as Our predecessor of happy memory, Leo XIII, in his Encyclical Satis Cognitum asserts: 'the Church is visible because she is a body. Hence they err in a matter of divine truth, who imagine the Church to be invisible, intangible, a something merely 'pneumatological' as they say, by which many Christian communities, though they differ from each other in their profession of faith, are untied by an invisible bond. ${ }^{11}$

Pius XII also responds to the Protestant notion of a church of the sanctified by noting that not all sin severs a member from the body here below. ${ }^{12}$ Thus the church counts sinful people among its members on this earth. Pius XII also incorporates the theology of Bellarmine when he refers to the church as a perfect society, which surpasses all other human societies. ${ }^{13}$

Ecclesiology, Vol 7, No. 2 (May 2011): pg. 147-172. DOI. This article is @ Brill Academic Publishers and permission has been granted for this version to appear in e-Publications@Marquette. Brill Academic Publishers does not grant permission for this article to be further copied/distributed or hosted elsewhere without the express permission from Brill Academic Publishers. 
In addition to responding to some of the polemics occasioned by the Reformation, Pius' retrieval of the biblical and patristic category of the body of Christ represents a development beyond Bellaramine's notion of the church as a perfect society. A major advantage of thinking of the church as the body of Christ is that it emphasizes the interdependence of the members of the body while simultaneously extending the concept of church beyond that of the institution. It is a model inclusive of all the members incorporated through baptism, so it is not an exclusively clerical or hierarchical model. It emphasizes the mission of the church as continuing the work of Christ.

Nevertheless, one disadvantage of the model of the church as the body of Christ is that it risks insufficiently differentiating between Christ and the church. For example, Pius XII's encyclical states that 'this Mystical Body which is the Church should be called Christ.'14 Here the church is seen as a prolongation of the Incarnation. This concept, when taken in isolation from other concepts of the church, is also criticized for its imperious exaltation of the church, for being ahistorical (and therefore not allowing sufficiently for development within the church), and for a notion of church membership that is too rigid (since one is either a member or not).

Two distinct and slightly different scriptural foundations for the church as body of Christ appearing in the New Testament not only illuminate this problem but also suggest a resolution. In the Epistles to the Ephesians and Colossians the relationship between Christ and the community is a covenanted one, standing in a relationship of head and body, for only in these epistles is Christ mentioned as the head of the body. By contrast, in 1 Corinthians 12 and Romans 12:4-8, Christ is equated with the entire body or community, membership in the body of Christ being conferred by baptism. The texts from Colossians and Ephesians, by emphasizing the distinction between the head and the body, distinguish the church from Christ more than the texts from First Corinthians and Romans do. This distinction between Christ and the church makes it impossible to identify the church as a prolongation of the Incarnation in such a way that the uniqueness and particularity of the historical Jesus Christ is lost, a danger faced by strict adherence to the body of Christ model. This distinction also assures that the church always remains subordinate to its head, Christ, and does not claim for

Ecclesiology, Vol 7, No. 2 (May 2011): pg. 147-172. DOI. This article is @ Brill Academic Publishers and permission has been granted for this version to appear in e-Publications@Marquette. Brill Academic Publishers does not grant permission for this article to be further copied/distributed or hosted elsewhere without the express permission from Brill Academic Publishers. 
itself what belongs uniquely to Christ. Vatican II's Lumen gentium, qualifies and nuances the relationship between the church and the body of Christ, in article 7.

A final problem with Pius XII's encyclical is that it exclusively identifies the Church of Christ with the Roman Church. ${ }^{15}$ This will be modified by Lumen gentium 's statement that the church, 'set up and organized in this world as a society, subsists in the catholic church, governed by the successor of Peter and the bishops in communion with him, although outside its structures many elements of sanctification and of truth are to be found which, as proper gifts to the church of Christ, impel towards catholic unity. ${ }^{16}$ This statement means that all the elements necessary for the church of Christ are present in the Roman Catholic Church, but they are not exclusively there.

\section{Eucharistic Ecclesiology}

The Catholic Church considers that 'the principal manifestation of the church consists in the full, active participation of all God's holy people in the same liturgical celebrations, especially in the same Eucharist, in one prayer, at one altar, at which the bishop presides, surrounded by his college of priests and by his ministers. ${ }^{17}$ This unity of celebration both signs and effects the unity of the mystical body of Christ, for the Eucharist is where the faithful are gathered together by the preaching of the gospel of Christ and the celebration of the Lord's Supper so that 'the whole fellowship is joined together through the flesh and blood of the Lord's body. ${ }^{18}$ According to this view, the Eucharist is constitutive of the church. Thus the church is sacramental, mystical, Christological, and pneumatological before it is sociological or juridical. The unity of the church is not psychological, political, or a federation of the like-minded, but a sacramental and spiritual unity in Christ first established in baptism and then expressed, nourished, and brought to maturity in eucharistic communion.

Although eucharistic ecclesiology does not figure as a separate 'model' of the church in the same way as Bellarmine's institutional emphasis, Pius XII's retrieval of the patristic and biblical image of the church as the body of Christ, or the later developments of Vatican II of the church as sacrament or people of God, the view of the church as 
the body of Christ integrates a theology of the church with the sacramental theology of the Eucharist within a Eucharistic ecclesiology. Within the sacramental life of the church, the Eucharist is not only the visible sign of communion in and with Christ, but is also constitutive of ecclesial communion, for in partaking of one bread we become one body ( 1 Corinthians 10:16-17). ${ }^{19}$ There is a density of ontological realism here that extends not only to the sacramental realism of the presence of Christ under the species of bread and wine, but also to the sacramental realism of the church, for where the Eucharist is, there is the church. There exists an intrinsic relationship between the historical Christ, the sacramental Christ of the Eucharist, and the ecclesial Christ. Church, sacrament, and historical person are different modes of existence of the same person seen through a theology of a real symbol or of an efficacious sacramentality.

Henri de Lubac was particularly instrumental in retrieving the ecclesial meaning of the eucharist in his historical study of the term Corpus Mysticum, where he traces its evolution from designating the eucharistic body to its use, from the middle of the twelfth century, to designate the ecclesial body. ${ }^{20}$ This linguistic shift accompanied a loss in the original perception of the unity between the body of Christ born of Mary, the eucharistic body, and the ecclesial body. Henceforth, Catholics were very resolute in affirming the real presence of Christ in the eucharist, the unity between the historical body and the sacramental body, but the connection between the sacramental body and the ecclesial body dropped out of consciousness. Pius' encyclical did much to affirm the unity of the historical body and the ecclesial body, but the ecclesial meaning of the eucharist in popular consciousness is still in need of strengthening. ${ }^{21}$

Sacramental realism thus exists on several levels: the body of Christ is truly present in the Eucharist and so is the ecclesial body, the church. This means not only that the church is present where the Eucharist is celebrated, but also that the church is sacramentalized, that is, signified and present, in the Eucharist. Affirmation of the Christological reality leads to the affirmation of the ecclesial reality. The presence of the latter is as real as the presence of the former. When we commune with the sacramental Body of Christ, we commune 
with the resurrected Christ and the church, which is also the Body of Christ.

Within this eucharistic ecclesiology there is an ontological density to the Eucharist by which a real communion of the members of the church is effected, both with each other and with and in Christ. This real communion does not deny the sacramental incorporation into Christ in baptism; instead, as the unity of the rites of initiation indicates, the Eucharist is the culmination of baptism. What is begun in baptism, namely, incorporation into Christ and into the church, finds both completion and repeated visible expression in the Eucharist.

A eucharistic ecclesiology perfectly expresses the creedal marks of the church as one, holy, catholic, and apostolic. The holiness of the church is communion in Christ by the power of the Spirit. The catholicity of the church embraces communion with the church's apostolic past as it obediently celebrates the Eucharist in memory of Christ. It communes with the saints in heaven. It constitutes the unity of the church as the unity of the mystical body of Christ.

The Roman Catholic Church shares this view of the church with many traditions, including Orthodox, Anglicans, and many Lutherans. For these traditions both baptism and Eucharist incorporate an individual simultaneously into Christ and into the church, the ecclesial body of Christ. One is a member of the church by virtue of being a member of Christ. For example, an agreed statement between the Orthodox and Roman Catholics stated in 1982:

Believers are baptized in the Spirit in the name of the Holy Trinity to form one body (cf. 1 Cor. 12:13). When the Church celebrates the eucharist, it realizes 'what it is,' the body of Christ (1 Cor. 10:17). ${ }^{22}$

The Report of the Anglican-Reformed International Commission (1981-84), God's Reign and Our Unity, likewise affirms the Eucharist as constitutive of the church: 'Along with baptism, the Eucharist is fundamental to and constitutive of the life of the Church. It is the sacrament given to the Church by her Lord for the continual renewal of her life in him. ${ }^{\prime 23}$ This statement affirms a liturgically-based identification of the church. 
NOT THE PUBLISHED VERSION; this is the author's final, peer-reviewed manuscript. The published version may be accessed by following the link in the citation at the bottom of the page.

\section{Church as Sacrament}

Three different articles in Lumen gentium identify the church as a sacrament, each with a slightly different nuance: the church as a sacrament or instrumental sign of intimate union with God and of the unity of all humanity (Article 1 ), the church as the universal sacrament of salvation (Article 48), and the church as the visible sacrament of saving unity (Article 9). The close association between union with God and the unity of humanity suggests that the salvation consisting in union with God does not exist apart from unity within humanity.

Since a sacrament is a visible form of invisible grace, ${ }^{24}$ there are two elements to a sacrament, a sign and a spiritual element conveyed by the sign. Yves Congar notes three occurrences of an identification of the church as sign in the Constitution on the Sacred Liturgy. ${ }^{25}$ In article 2 the church is 'an ensign raised for the nations, under which the scattered children of God can be brought together into one until there is one fold and one shepherd'. Article 5 speaks of the sacrament of the whole church arising from the side of Christ as he slept on the cross. Article 26 cautions against a privatization of the liturgy, noting that 'liturgical events are not private actions but celebrations of the church which is "the sacrament of unity", the holy people drawn into an ordered whole under the bishops.' The first and third of these passages stress the church as a sacrament or sign of unity while the second passage associates the church with the blood and water issuing from the side of Jesus, symbols of the sacraments baptism and Eucharist.

The identification of the church as a sacrament also occurs within a chain of sacramentality in the theological writing of Edward Schillebeeckx and Karl Rahner. ${ }^{26}$ In the theology of the latter, Christ, the primordial sacrament, is a sacrament of the Father. The church is a sacrament of Christ, and the seven sacraments are sacraments of the church. The sign or sacrament makes present in the world of that which is signified, namely, God, Christ, and the church, respectively. This model can be diagramed thus:

$\mathrm{God} \rightarrow \mathrm{Christ} \rightarrow \mathrm{Church} \rightarrow \mathrm{Sacrament}$

Ecclesiology, Vol 7, No. 2 (May 2011): pg. 147-172. DOI. This article is @ Brill Academic Publishers and permission has been granted for this version to appear in e-Publications@Marquette. Brill Academic Publishers does not grant permission for this article to be further copied/distributed or hosted elsewhere without the express permission from Brill Academic Publishers. 
The idea of the church as sacrament is closely related to the image of the body of Christ. From a biblical perspective, the body is that which makes a person present and active. The church as the body of Christ is the sacramental presence of Christ in the world analogously to how Christ is the sacrament of the Father. As Jesus said, those who know him know the Father. Those who see him see the Father (John $14: 7,9)$.

In the case of the church, the visible sign includes the institutional and social aspects of the church, that is, all that is manifest in history and located in space and time. The referent of the sign is the resurrected Christ. As with the Incarnation, in the church there exists the union of the divine and the human, with the human being the manifestation and revelation of the divine. Henri De Lubac draws this analogy: 'If Christ is the sacrament of God, the Church is for us the sacrament of Christ. ${ }^{27}$ The human element becomes the manifestation and revelation of the divine. Lumen gentium expresses this relationship as follows:

This society, however, equipped with hierarchical structures, and the mystical body of Christ, a visible assembly and a spiritual community, an earthly church and a church enriched with heavenly gifts, must not be considered as two things, but as forming one complex reality comprising a human and a divine element. It is therefore by no mean analogy that it is likened to the mystery of the incarnate Word. For just as the assumed nature serves the divine Word as a living instrument of salvation inseparably joined with him, in a similar way the social structure of the church serves the Spirit who vivifies the church towards the growth of the body (see Eph. 4, 16). ${ }^{28}$

Even though the concept of the church as the sacrament of Christ is closely related to the image of the church as the mystical body of Christ, it escapes a major weakness of this image by avoiding too close of an identification between Christ and the church. The concept of sacrament is able to express the unity between the sign and the referent of that sign at the same time that it maintains the distinction between them, because what is signified is not absolutely identical with the sign that makes it present. This unity amidst distinction is analogous to the relationship between the divine and human natures in Christ, here noted by Rahner: 'as with Christ the

Ecclesiology, Vol 7, No. 2 (May 2011): pg. 147-172. DOI. This article is @ Brill Academic Publishers and permission has been granted for this version to appear in e-Publications@Marquette. Brill Academic Publishers does not grant permission for this article to be further copied/distributed or hosted elsewhere without the express permission from Brill Academic Publishers. 
distinction between his Godhead and his humanity remains without confusion though they are inseparable signs and reality, manifest historical form and Holy Spirit are not the same in the Church, but as in Christ, are not separable any more either.' ${ }^{29}$

As we have seen, the church is most visibly a sign of grace and union with Christ in the Eucharist since the Eucharist is 'indivisibly Christological and ecclesiological'. ${ }^{30}$ The Eucharist is both the sign and the instrument of the union of the People of God with God and with one another. However, not only the Eucharist, but also all the sacraments have the church as their referent, which is to say that sacraments are signs of the church. They not only belong to the church, but make the church manifest as self-expressions of the church. They are 'the essential functions that bring into activity the very essence of the Church'. ${ }^{31}$

The nature of the church is evident through each of the sacraments. In the Eucharist we know the church to be the body of Christ. We are incorporated into that body, both the church and the body of Christ, in baptism. We are reconciled to both Christ and the church in the sacrament of penance. Marriage, the covenant between two human beings, is a sign of the relationship between Christ and the church. So, too, what is 'ordered' in the Sacrament of Order is the church. In this sacrament the ordained person is ordered to both Christ and the church in such a way that the ordained is representative of both.

The document from the World Council of Churches, The Nature and Mission of the Church, identifies the sacramental nature of the church as a disputed concept that still divides the churches. While the churches agree that the church is a sign and instrument some churches object to this concept because

1. the need for a clear distinction between the church and sacraments; the sacraments are the means of salvation, through which Christ sustains the church, and not actions by which the church realizes or actualizes itself; and

2. the use of the word 'sacrament' for the church obscures the fact that, for them, the church is a sign and instrument of God's

Ecclesiology, Vol 7, No. 2 (May 2011): pg. 147-172. DOI. This article is @ Brill Academic Publishers and permission has been granted for this version to appear in e-Publications@Marquette. Brill Academic Publishers does not grant permission for this article to be further copied/distributed or hosted elsewhere without the express permission from Brill Academic Publishers. 
intention and plan - but it is so as a communion, which, while being holy, is still subject to $\sin .^{32}$

The document acknowledges that those churches that use the expression do so because they understand the church to be 'an effective sign of what God wishes for the world, namely the communion of all together with the Triune God. ${ }^{\prime 3}$ Thus, according to this understanding, the sacraments are not only means of grace, but also effective signs of grace.

In answer to these objections to the idea of the church as sacrament, it is important to note that the notion of sacramentality when applied to the church is an analogous concept, not a univocal one. The Latin of Lumen gentium, $\S 1$ says the church is veluti sacramentum, a sort of sacrament. As mentioned earlier, the concept of sacrament is able to express the unity between the sign and the referent of that sign at the same time that it maintains the distinction between sign and referent. This unity and distinction is analogous to the relationship between the divine and human natures in Christ. However, strictly speaking, the church is not a prolongation of the incarnation, but a sacrament of the incarnation, that which enables Christ to act sacramentally in the world. This relationship allows the Roman Catholic Church to assert the holiness of the church as the body of Christ and temple of the Spirit at the same time that it allows for the sinfulness of the church's members. In the case of the church, the visible sign includes the institutional and social aspects of the church, that is, all that is manifest in history and located in space and time. The referent of the sign, however, is the resurrected Christ himself. It is important not to confuse the sign with its referent. As with the Incarnation, in the church there is the union of the divine and the human, the human being the manifestation and revelation of the divine while the necessary distinction between the two is maintained.

As for the objection that this concept of the church as sacrament implies that sacraments are merely moments in the church's process of self-realization, we must remember that sacraments are to be interpreted as acts of Christ. If the church is realized through baptism and the Eucharist, this is only possible through the sacramental realism of each: in the first through 
incorporation into the death and rising of Christ, and in the second by incorporation into the risen Christ (1 Corinthians 10:16-17). By being assimilated into Christ in the Eucharist, we are not only joined to Christ but also to all others who are likewise joined to Christ by the power of the Spirit. At all times the church is instituted by Christ and constituted by the Holy Spirit. This does not constitute the selfrealization of the church, but its realization through the agency of Christ and his Spirit.

The concept of the church as sacrament integrates the previous two models, the church as institution and perfect society and the church as the mystical body of Christ. Since all sacraments have an outward element, the sign of the sacrament, this assures the visibility of the church and underscores the importance of faith becoming visible through its public profession, communion in the sacraments, and unity with the ordained ministry charged with promoting and maintaining the unity and communion of the church. At the same time, the concept of sacrament avoids some of the dangers of the concept of church as the body of Christ and as prolongation of the incarnation since a sacrament is the real presence of what it signifies under the modality of sign.

A number of consequences flow from the sacramentality of the church. First, the basis for authority in the church is the Lordship of Christ and his continuing presence in the power of the Spirit. As Guiseppe Alberigo comments, '... in the church the source of all responsibility and all mandates to service lies in Christ and these can be participated in only by means of a sacramental act.'34 The authority of the ordained minister is conferred sacramentally and exercised within a eucharistic community. The ordained minister represents the person of Christ as Head of the community that is the body of Christ. Through its sacramentality, the church is the corporate presence of God in Christ in the unity of the Spirit. The church's missionary obligation is to manifest what it embodies. As a sign it must manifest in its external structure the values it professes. One consequence of this obligation is that the church, which speaks to others about justice, must be just itself in its own institutions and in its dealings with its members and with others outside the visible boundaries of the Roman

Ecclesiology, Vol 7, No. 2 (May 2011): pg. 147-172. DOI. This article is @ Brill Academic Publishers and permission has been granted for this version to appear in e-Publications@Marquette. Brill Academic Publishers does not grant permission for this article to be further copied/distributed or hosted elsewhere without the express permission from Brill Academic Publishers. 
Catholic Church. Not to do so prevents the church from being a clear and unambiguous sign of the presence of Christ in the world.

Second, the church as sacrament is inseparable from its baptismal and Eucharistic practices, for the unity of the church is sacramentally realized in its communion with its Lord (1 Corinthians $10: 16-17)$. Therefore the principles of good worship are also the principles of life in the church more generally, since the nature of the church is manifested through the liturgy. ${ }^{35}$ Specifically this means that insofar as the nature of the liturgy requires the 'full, conscious, and active participation' of the faithful in liturgical celebrations, so also must the faithful participate in the church fully, consciously, and actively. ${ }^{36}$ This does not mean turning the church into a political democracy, however, although it does mean incorporating liturgical principles into the governance of the church.

Third, the sacramentality of the church requires that pastoral leadership and liturgical presidency be united in the normal practice of the church. The minister who presides over the unity of the community generally should preside over the sacrament of unity, the Eucharist. Presidency refers to the ecclesial life of the community before it refers to a liturgical action. ${ }^{37}$ Ministry is first a pastoral charge before it is a liturgical function. This practice emphasizes the intrinsic connection between the nature of the church and its liturgical worship, as well as the relationship between a pastoral liturgical minister and the church.

Fourth, when the sacramentality of the church is viewed from the perspective of the Eucharist with all its implications for unity and communion within the church, it becomes evident that governance is personal, collegial, and communal. Although it is very clear in the Roman Catholic Church that the ultimate authority for a parish rests with the pastor, the diocese with its bishop, and the universal church with the pope, in reality there exists a rich network of relationships within which each of these authorities operates. Pastors govern in communion with and under the authority of their bishop. Bishops govern in communion with the college of bishops and the Bishop of Rome. The Bishop of Rome, even when acting alone, is acting implicitly as the head of the college of bishops.

Ecclesiology, Vol 7, No. 2 (May 2011): pg. 147-172. DOI. This article is @ Brill Academic Publishers and permission has been granted for this version to appear in e-Publications@Marquette. Brill Academic Publishers does not grant permission for this article to be further copied/distributed or hosted elsewhere without the express permission from Brill Academic Publishers. 
NOT THE PUBLISHED VERSION; this is the author's final, peer-reviewed manuscript. The published version may be accessed by following the link in the citation at the bottom of the page.

\section{Church as People of God}

The second chapter of Lumen gentium introduces the notion of the people of God between the first chapter 'On the Mystery of the Church' and the third chapter 'The Church is Hierarchical'. This concept balances out the notion of the church as Body of Christ and the church as perfect society because 'the people of God' represents a dynamic and historical image of the church as it journeys toward its eschatological goal as a pilgrim people. In this model, history is especially valued as the medium of God's revelation. Since the people of God are those people chosen by God, it includes the notion of God's preferential love for his people and new beginnings in grace. This concept allows for development and growth in the church. It stresses continuity with the people of God of the Old Testament and yet announces the newness of the new covenant in Christ. The concept of the people of God offers an ecumenical bridge to other Christians through acknowledging those elements we share with them in the scriptures, in our common belief in the Triune God, and in participation in one baptism. Others also possess the episcopate, celebrate the Eucharist, and share devotion to the Mother of God. ${ }^{38}$ Even with nonChristians, the church shares acknowledgement of the Creator and the possibility of salvation for those who seek God with a sincere heart. ${ }^{39}$

Chapter two is important not only because of the concepts it develops, but because of its place in the Constitution since it addresses what all the baptized share in common and treats the quality of a disciple before consideration of offices in the church or of particular states in life. The church is first and foremost the people who respond to God's call of grace before it is an institution or the totality of the objective means of grace. ${ }^{40}$ When viewed as the people of God, the church is not exclusively identified with the hierarchy or its juridical organization, but is the communion of its members, an understanding that has led to a renewed theology of the laity.

Nevertheless, just as each of the former views of the church incorporated the previous models even while balancing them with additional new elements, so does the church as the people of God retain the importance of the institution and the objective means of grace, expressing them in terms reminiscent of Bellarmine:

Ecclesiology, Vol 7, No. 2 (May 2011): pg. 147-172. DOI. This article is @ Brill Academic Publishers and permission has been granted for this version to appear in e-Publications@Marquette. Brill Academic Publishers does not grant permission for this article to be further copied/distributed or hosted elsewhere without the express permission from Brill Academic Publishers. 
Fully incorporated into the society of the church are those who, possessing the Spirit of Christ, accept its entire structure and all the means of salvation established within it and who in its visible structure are united with Christ, who rules it through the Supreme Pontiff and the bishops, by the bonds of professions of faith, the sacraments, ecclesiastical government, and communion. ${ }^{41}$

This institutional description, however, ends with the admonition: 'A person who does not persevere in charity, however, is not saved, even though incorporated into the church.' Such people remain indeed in the bosom of the church, but only 'bodily' not 'in their hearts. ${ }^{\prime 2}$ This chapter reaffirms elements in both the church as sacrament and the eucharistic character of the church as body of Christ in its assertion that the church is a 'visible sacrament of saving unity ${ }^{\prime 43}$ and in its identification of the people of God as a priestly, prophetic, and kingly community for whom 'the Eucharistic sacrifice is the source and summit of the Christian life. ${ }^{\prime 44}$ This charismatic people, anointed by the Spirit, possess a sense of the faith by which they cannot be mistaken in belief. ${ }^{45}$

The church as people of God is not a democratic organization, but is a 'type of an organic body possessing members and a head and therefore with a certain hierarchical order'. ${ }^{46}$ Even though the People of God are those 'who in faith look towards Jesus, the author of salvation and the principle of unity and peace', ${ }^{47}$ the priestly community that this people forms is 'brought into operation through the sacraments and the exercise of virtues'. ${ }^{48}$ Baptism is the sacrament of faith and the objective means by which a person participates in the new People of God. ${ }^{49}$ The People of God is an ordered people with a variety of orders within the church. Chapter 3 of Lumen gentium still speaks of a 'hierarchically constituted society'. ${ }^{50}$ This society is organized on a sacramental basis through the consecrations of baptism, confirmation, and orders. The category 'People of God' is able to encompass both the equality of the faithful in the dignity of Christian existence and their functional differentiation within the church. 
NOT THE PUBLISHED VERSION; this is the author's final, peer-reviewed manuscript. The published version may be accessed by following the link in the citation at the bottom of the page.

\section{Church as Communion}

In 1985 the Extraordinary Synod of bishops determined that communion was the dominant image of the church at the council. ${ }^{51}$ In June 1992 the Congregation for the Doctrine of the Faith issued a letter to the bishops of the Catholic Church, entitled 'Some Aspects of the Church Understood as Communion'. Recent theological reflections on the church are integrating the theme of communion into systematic accounts of a theology of the church, and it is proving to be a fruitful category for ecumenical agreements. ${ }^{52}$

'Communion' integrates the two dominant images of the church at the time of the Second Vatican Council: the church as the body of Christ and the church as the people of God. This communion is effected by participation in baptism and the Eucharist and modelled on the communion or perichoresis of the Father, the Son, and the Spirit in their mutual Trinitarian relationships. Thus the primary emphasis of communion consists in the elements of grace and sacrament that ultimately identify ecclesial communities in terms of their relationship to Christ.

Ecclesial communion envisioned as communion in Christ unifies other systematic themes. Thus, the eschaton recapitulates all creation in Christ Jesus. The Epistle to the Colossians describes this as a 'reconciliation (Colossians 1:20). The mission of the church, when conceived of as work for this final recapitulation, extends the concept of reconciliation from one of juridical penance and repentance for sin to one of incorporation into the body. The dominant metaphor for sin becomes alienation and isolation from the body of Christ, and the metaphor for grace is communion within the body. This is more than a horizontal reconciliation of the human community to itself, but reconciliation to Christ, the head of the body, and reconciliation to life in the Trinity through incorporation into Christ (2 Corinthians 5:1821). In Catholic ecclesiology, the church is gathered by the preaching of the word and the celebration of the Lord's Supper under the sacred ministry of the bishop. ${ }^{53}$ The Roman Catholic Church identifies the basic unit of the church as the altar community gathered around the bishop. ${ }^{54}$ This is not the congregation, but the diocese, since the diocese is a portion of the people of God governed by a bishop. Thus

Ecclesiology, Vol 7, No. 2 (May 2011): pg. 147-172. DOI. This article is @ Brill Academic Publishers and permission has been granted for this version to appear in e-Publications@Marquette. Brill Academic Publishers does not grant permission for this article to be further copied/distributed or hosted elsewhere without the express permission from Brill Academic Publishers. 
the church is identified eucharistically and ministerially, with the apostolic episcopal ministry considered to be essential.

The bishop then represents this community in the communion of particular churches, the bishops collectively in the college of bishops representing in their person the communion of churches in union with the Church of Rome and its bishop. ${ }^{55}$ The Bishop of Rome exercises the Petrine ministry, defined as the charge to safeguard the church in a unity of faith and communion. ${ }^{56}$ Thus the sacramental communion initiated in baptism and the Eucharist is lived out in institutional relationships as well as in personal relationships. The church is thus identified as a communion of communions. ${ }^{57}$

Communion ecclesiology, in contrast to ecclesiologies emphasizing the church as the Mystical Body, the People of God, or perfect society, emphasizes the local, particular church and its relationship to the other local churches as well as to the universal church. This local church as a eucharistic community cannot exist alone as church all by itself, but must be united to its bishop and through the bishop to all the other eucharistic communities within the church. The local church, although wholly church, is not the whole church.

The universal church is the communion of these altar communities, a 'communion of communions', that is, a communion of particular churches in which there is a relationship of mutual interiority between the particular church and the universal church. The universal church is one, although it subsists in each particular church analogously to how the eucharist or body of Christ is present on many altars although there is only one body. ${ }^{58} \mathrm{~A}$ primary function of pastoral leadership is to maintain the community in unity and communion, both within the local church and with the other local churches. Governance and liturgical presidency coincide, since the presider at the Eucharist, the sacrament of ecclesial unity, and the person responsible for maintaining the community in unity is one and the same - that is, the bishop or his delegate presbyters. Liturgical presidency is the sacramentalization of that person's role in the community.

Ecclesiology, Vol 7, No. 2 (May 2011): pg. 147-172. DOI. This article is @ Brill Academic Publishers and permission has been granted for this version to appear in e-Publications@Marquette. Brill Academic Publishers does not grant permission for this article to be further copied/distributed or hosted elsewhere without the express permission from Brill Academic Publishers. 
Through the episcopacy the particular church is related to the universal church since a primary function of the bishop is to represent the particular church in the communion of churches through his membership in the episcopal college. This correlation of the particular with the universal is evident by the fact that a Christian becomes bishop only through his admission to the undivided body of the episcopacy.'59 Thus even though the particular church is manifested in its eucharistic worship in a specific place under the leadership of an individual bishop, it exists only in its reference to the whole church. The whole church, in its undivided episcopacy, ordains a bishop. Each bishop has the responsibility to be solicitous for the entire church. ${ }^{60}$

In this model each particular church is in communion with every other particular church as well as with the Bishop of Rome, who exercises the ministry of safeguarding the unity and communion of the particular churches. This communion is personalized and objectively sacramentalized in the college of bishops to which each bishop is admitted upon consecration. The bishops in their persons represent their churches. This image illustrates the relationship between the college of bishops and the communion of particular churches.

Within this model, ordained ministry is the sacramentalization of ecclesial relationships. This means that the bishops in their relationship of communion within the college of bishops are the visible sign and representation of the communion of the particular churches. Membership in and union with the college of bishops is an essential element within episcopal ordination and arguably represents the 'fullness of orders' which sets the episcopacy apart from the other orders, namely the presbyterate and the diaconate. ${ }^{61}$ Each bishop represents his particular church, and together the episcopal college represents the communion of churches. What is sacramentally signified in episcopal ordination is the collegial nature of the church as a 'communion of communions'. The college of bishops symbolizes the unity that exists among the altar communities and which each bishop represents in his office. The order of the episcopacy truly reflects the ordering among eucharistic communities.

Ecclesiology, Vol 7, No. 2 (May 2011): pg. 147-172. DOI. This article is @ Brill Academic Publishers and permission has been granted for this version to appear in e-Publications@Marquette. Brill Academic Publishers does not grant permission for this article to be further copied/distributed or hosted elsewhere without the express permission from Brill Academic Publishers. 


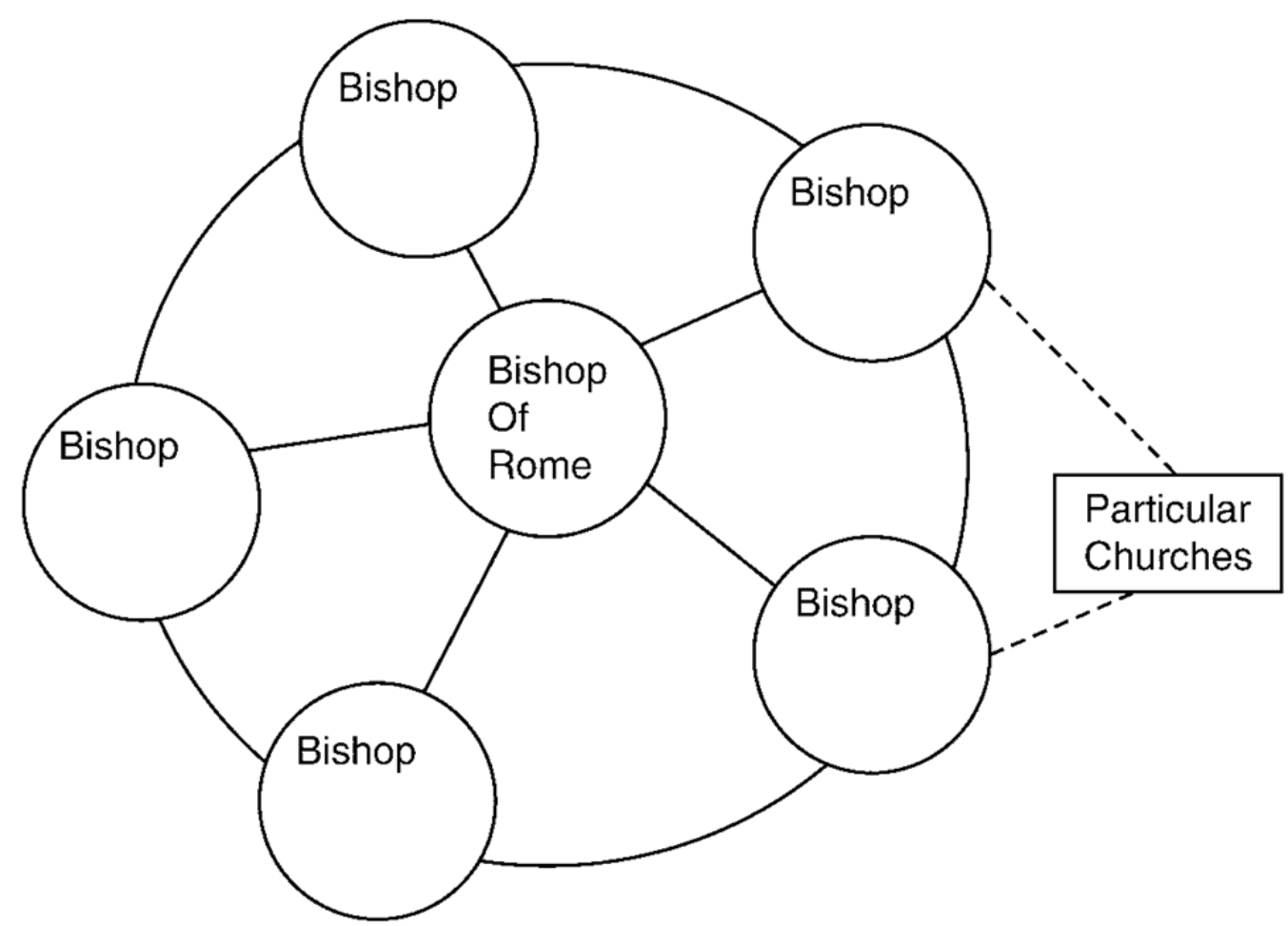

The personal dimension of the relationship among church communities functions both synchronically and diachronically, that is, within the communion of churches now extant throughout the world as well as within the historical communion of churches linked together in apostolic succession. Thus in Roman Catholicism there is an emphasis on the succession of laying on of hands to signify the apostolic succession of faith communities. Nevertheless, this succession cannot be historically substantiated in the earliest period, and although a sign of succession in apostolic faith, it cannot be a guarantee of apostolic faith since the apostasy of a bishop in succession remains a possibility. Apostolic succession is both a succession in personal ministry and a succession of communities of faith. In many ways this relationship recalls Cyprian's words, 'the bishop is in the church and the church is in the bishop'.62

The Bishop of Rome exercises an important function in working for the unity and communion of all the particular churches, a ministry called the 'Petrine ministry'. In the words of Vatican II: 'in order that the episcopate itself, however, might be one and undivided [Christ] placed blessed Peter over the other apostles and in him he set up a lasting and visible source and foundation of the unity both of faith and

Ecclesiology, Vol 7, No. 2 (May 2011): pg. 147-172. DOI. This article is @ Brill Academic Publishers and permission has been granted for this version to appear in e-Publications@Marquette. Brill Academic Publishers does not grant permission for this article to be further copied/distributed or hosted elsewhere without the express permission from Brill Academic Publishers. 
communion. ${ }^{63}$ This function of Peter, continued in the institution of the papacy, does not diminish the role of the bishops or the proper autonomy of the local churches, but strengthens them. The relationship between the local churches and the universal church can be summarized by the following theses:

1. There is only one church of Christ. Catholics believe that this one church is present in the Roman Catholic Church although ecclesial elements are also found outside it. Vatican II stated: 'The church, constituted and organized as a society in the present world, subsists in the Catholic Church, which is governed by the successor of Peter and by the bishops in communion with him. ${ }^{64}$ This represents a development from Pius XII's Mystici Corporis, which identified the Church of Christ with the Catholic Church.

2. The particular churches are formed in the likeness of the universal church; in and from these particular churches there exists the one unique Catholic Church. ${ }^{65}$ This means that the universal church does not have more than a notional existence unless it exists in and out of the local churches. The mystery of the church is present and manifested in a concrete society. The many churches are not churches except in the one church; the one church does not exist except in and out of the many churches.

3. The universal church is not a federation of particular churches.

4. A particular church is not a sub-unit or branch office of the universal church.

5. A particular church is wholly church, but not the whole church.

6. The universal church exists only as the communion of the particular or local churches. Joseph Komonchak suggests that it may be asked 'whether this does not require that all statements about the universal church be realized and verified in and among the particular churches, in other words, whether what is called the universal church is a subject of attribution and of activity apart from the particular churches'. ${ }^{66}$

7. The only place in which one can encounter the universal church is in the particular church. 
In addition to communion in ministry and the communion of particular churches within the worldwide church, communion in faith must necessarily characterize the Catholic Church. The church believes and trusts Christ's promise that he will remain with his church until the end of time. The principle that Christ will preserve the church in the truth necessary for salvation is called indefectibility. The possibility of remaining in this truth requires both a teaching authority that can teach this truth with inerrancy and a sense of the faith (sensus fi dei) that apprehends it unerringly. This sense of the faith is an attribute of the faithful as a whole (sensus fi delium):

The universal body of the faithful who have received the anointing of the holy one (see $1 \mathrm{Jn}$. 2:20 and 27), cannot be mistaken in belief. It displays this particular quality through a supernatural sense of the faith in the whole people when 'from the bishops to the last of the faithful laity', it expresses the consent of all in matters of faith and morals. Through this sense of faith which is aroused and sustained by the Spirit of truth, the people of God, under the guidance of the sacred magisterium to which it is faithfully obedient, receives no longer the words of human beings but truly the word of God (see 1 Th. 2, 13); it adheres indefectibly to 'the faith which was once for all delivered to the saints' (Jude 3); it penetrates more deeply into that same faith through right judgment and applies it more fully to life. ${ }^{67}$

This sense of the faith of all the people of God may be of the order of a recognition, a sort of connatural inchoate resonance with the truth when they meet it; however, it belongs to the magisterium, the teaching office of the bishops and the bishop of Rome, to give the faith explicit articulation. Infallibility is the gift of the Holy Spirit which preserves the church in its teaching and its members in believing from error regarding revelation. Infallible teaching articulates an article of faith as being irreformably and irrevocably true.

Infallible teaching is possible through three avenues in the church. First, although individual bishops do not possess the prerogative of teaching infallibly, 'even though dispersed throughout the world, but maintaining the bond of communion among themselves and with the successor of Peter, when in teaching authentically matters concerning faith and morals they agree about a judgement as one that has to be definitely held, they infallibly proclaim the teaching

Ecclesiology, Vol 7, No. 2 (May 2011): pg. 147-172. DOI. This article is @ Brill Academic Publishers and permission has been granted for this version to appear in e-Publications@Marquette. Brill Academic Publishers does not grant permission for this article to be further copied/distributed or hosted elsewhere without the express permission from Brill Academic Publishers. 
of Christ'. ${ }^{68}$ Second, the bishops can teach infallibly when gathered in union with the bishop of Rome in an ecumenical council. Third, 'The Roman Pontiff, when he speaks ex cathedra, that is, when he discharges his office as pastor and teacher of all Christians, and in virtue of his supreme apostolic authority, defines a doctrine concerning faith or morals that is to be held by the universal church, through the divine assistance promised him in St. Peter, exercises that infallibility with which the divine Redeemer willed to endow his church. ${ }^{\prime 69}$ For example, the two Marian dogmas, the Immaculate Conception (1854) and the Assumption (1950), were promulgated by this third method of teaching infallibly.

The doctrine of infallibility does not mean that the manner in which a doctrine is formulated cannot be improved or changed over time. Indeed, sometimes formulations have to change in order that the underlying intent or meaning of the formulation remains clean. Nor does the doctrine of infallibility prevent the church from making mistakes in teaching, or prevent the members from mistakes in believing, matters other than those truths of revelation necessary for salvation. Catholics understand infallibility as divinely given assistance for faithfully believing and authoritatively proclaiming the authentic message of the gospel. Although the teaching on infallibility predates the contemporary emphasis on communion ecclesiology, it pertains to the ministry of the bishops, particularly the bishop of Rome in his Petrine ministry, to keep the church in communion with its apostolic past and so with apostolic teaching.

The doctrine of infallibility remains, however, one of the most controversial issues separating Roman Catholics and other Christians, and even within Roman Catholicism it has been subject to varying interpretations since Vatican I. At times, consensus can be reached that the church, established by Christ and led by his Spirit, will always remain in the truth fulfilling its mission to humanity for the sake of the Gospel. ${ }^{70}$ However, much more ecumenical work still remains to be done on those conditions necessary for the church to teach the Gospel authentically.

Ecclesiology, Vol 7, No. 2 (May 2011): pg. 147-172. DOI. This article is @ Brill Academic Publishers and permission has been granted for this version to appear in e-Publications@Marquette. Brill Academic Publishers does not grant permission for this article to be further copied/distributed or hosted elsewhere without the express permission from Brill Academic Publishers. 
NOT THE PUBLISHED VERSION; this is the author's final, peer-reviewed manuscript. The published version may be accessed by following the link in the citation at the bottom of the page.

\section{Conclusion}

These five conceptualizations - perfect society, body of Christ, sacrament, people of God, and communion - consistently portray the church as a visible society united by profession of faith, communion in the sacraments, and unity with an ordained apostolic ministry. The church community, instituted by and founded on Christ, is liturgically constituted as the people of God, body of Christ, and temple of the Spirit in baptism and the Eucharist. Its mission is implicit in its very identity as sacrament of the intimate union of God and the unity of all humanity. That is, its mission is to promote the communion with all people in union with God. This is none other than a ministry of reconciliation of all in Christ.

The historical succession of the various conceptualizations represents development, balance, correction, and a deeper penetration in the understanding and articulation of the prior conceptualizations. The church as body of Christ develops the spiritual and Christological dimension of the church as society. The church as sacrament offers a way of differentiating between Christ and the church while at the same time retaining the close correlation between the two. The church as people of God introduces historical consciousness into the definition of the church. The church as communion synthesizes the strong sacramental and spiritual identity of the church with its organizational structure.

Thus it would be erroneous to assume that succeeding models simply discard previous models as outdated or erroneous. The continuity and correction demonstrates the living tradition of ecclesiology as reflection on the church to be an organic development rather than an abrupt change of mind. Not only the life of the church, but the very concept of the church experiences a continuous purification and reform, ${ }^{71}$ but one in which the outlines of the church always remain recognizable.

Reflection on the nature of the church, of course continues. Further developments in Roman Catholic ecclesiology are desirable. For instance, Roman Catholic ecclesiology since Vatican II is challenged to incorporate a stronger and more explicit pneumatology

Ecclesiology, Vol 7, No. 2 (May 2011): pg. 147-172. DOI. This article is @ Brill Academic Publishers and permission has been granted for this version to appear in e-Publications@Marquette. Brill Academic Publishers does not grant permission for this article to be further copied/distributed or hosted elsewhere without the express permission from Brill Academic Publishers. 
in its articulation of the church. The church is not only instituted by Christ, but also constituted by the Spirit. The eucharistic epiclesis, the invocation of the Spirit, asks that those present might become the body of Christ. Thus a pneumatology is already present in the categories examined here, even though it is fair to say that Christology has dominated Catholic ecclesiology.

Finally, even though the parish, the local congregation, is not a church in a full sense, there is a need to give a fuller account of the parish since that is where most Roman Catholics experience the church. The Rite of Christian Initiation of Adults, when fully implemented, contains an implicit theology of the parish as a ministerial community with a variety of roles for the evangelization, initiation, and continuing formation of Christians. A theological account of the parish necessitates a theology of the laity as subjects in the church - another topic awaiting development.

\section{Notes}

*. An earlier version of this essay was written for the Roman Catholic-Baptist World Alliance Conservations 13-19 December 2009 was an overview of Catholic ecclesiology. 'Roman' is used in this essay to distinguish the Roman Catholic Church from Anglicanism and other traditions that consider themselves catholic. It is not meant to exclude Eastern Catholics in communion with Rome.

1. The earliest treatise of ecclesiology is generally considered to be James of Viterbo's On Christian Government (1301-1302), while the earliest systematic treatise of ecclesiology is usually attributed to John of Torquemada for his Summa on the Church (1436).

2. Articulated by Clement of Rome in 1 Clement, 96 C.E.; see also Irenaeus, Adv. Haer. III, 2, 1.

3. The earliest unmistakable evidence of a monarchical episcopate is in the letters of Ignatius of Antioch, ca. 110.

4. Lumen gentium, 21.

5. See Lumen gentium, 23.

6. See Unitatis Redintegratio, Chapter III; Dominus Jesus, 6 August 2000, 17.

7. Augsburg Confession, Art. 7, 8. Read this in connection with Luther's statement that 'the church is hidden and the saints unknown' in $D e$ servo arbito, D. Martin Luthers Werke (Weimar, 1883- ) 18:652; cited in Michael Himes, 'The Development of Ecclesiology: Modernity to the Twentieth Century', in The Gift of the Church, ed. Peter Phan (Collegeville: Liturgical Press, 2000), p. 47. Actually, Luther never taught that the church was invisible, but only hidden.

Ecclesiology, Vol 7, No. 2 (May 2011): pg. 147-172. DOI. This article is @ Brill Academic Publishers and permission has been granted for this version to appear in e-Publications@Marquette. Brill Academic Publishers does not grant permission for this article to be further copied/distributed or hosted elsewhere without the express permission from Brill Academic Publishers. 
8. De controversiis, tom. 2, liber 3, De ecclesia militante, cap. 2, De definitione Ecclesiae (Naples: Giuliano, 1857), 2:75; trans. and quoted by Avery Dulles in Models of the Church, expanded ed. (New York: Doubleday, 1987), p. 16.

9. Ibid.

10. Pius XII, Mystici Corporis, 12.

11. Ibid., 14, citing Leo XIII, Satis Cognitum, C.f. A.S.S., XXVIII, p. 710.

12. Ibid., 23.

13. Ibid., 63.

14. Ibid., 34.

15. Ibid., 13: '... this true Church of Jesus Christ - which is the One, Holy, Catholic, Apostolic and Roman Church.'

16. Lumen gentium, 8.

17. Sacrosanctum Concilium, 41.

18. Lumen gentium, 26.

19. For eucharistic ecclesiology see Henri de Lubac, Corpus Mysticum:

L'Eucharistie et L'Église au moyen age, 2nd Ed. (Paris: Aubier, 1949) and Catholicisme: Les aspects sociaux du dogme, 7e (Paris: Cerf, 1983), chapter 48; Paul McPartlan, The Eucharist Makes the Church: Henri de Lubac and John Zizioulas in Dialogue (Edinburgh: T\&T Clark, 1993); Sacrament of Salvation: An Introduction to Eucharistic Theology (Edinburgh: T\&T Clark, 1995); 'Eucharistic Ecclesiology', One in Christ (22, no. 4, 1985), pp. 314-331; and J. M. R. Tillard, Flesh of the Church, Flesh of Christ: At the Source of the Ecclesiology of Communion, trans. by Madeleine Beaumont (Collegeville: Liturgical Press, 2001). For an Orthodox perspective see John Zizioulas, Eucharist, Bishop Church: The Unity of the Church in the Divine Eucharist and the Bishop during the First Three Centuries, trans. by Elizabeth Theokritoff (Brookline, Mass.: Holy Cross Orthodox Press, 2001).

20. See Corpus Mysticum, cited above; Susan K. Wood, Spiritual Exegesis and the Church in the Theology of Henri de Lubac (Eugene Oregon: Wipf \& Stock, 2010), chapter 3.

21. Frank Senn in The People's Work: A Social History of the Liturgy

(Minneapolis: Fortress Press, 2006) narrates the story of the Eucharist as the expression of ecclesial unity and thus social unity in the Middle Ages and the subsequent loss of this unity under the influence of the Reformation in chapters 10 and 11 .

22. Joint International Commission, 'The Mystery of the Church and of the Eucharist in the Light of the Mystery of the Holy Trinity' (1982) in The Quest for Unity: Orthodox and Catholics in Dialogue. Documents of the Joint International Commission and Official Dialogues in the United States 1965-1995, ed. by John Borelli and John H. Erickson

Ecclesiology, Vol 7, No. 2 (May 2011): pg. 147-172. DOI. This article is @ Brill Academic Publishers and permission has been granted for this version to appear in e-Publications@Marquette. Brill Academic Publishers does not grant permission for this article to be further copied/distributed or hosted elsewhere without the express permission from Brill Academic Publishers. 
NOT THE PUBLISHED VERSION; this is the author's final, peer-reviewed manuscript. The published version may be accessed by following the link in the citation at the bottom of the page.

(Washington, D.C.: United States Catholic Conference and Crestwood, New York: St. Vladimir's Seminary Press, 1996), pp. 54-55, I 4 (b).

23. Anglican-Reformed International Commission (1981-84), God's Reign and Our Unity, $\S 71(\mathrm{~g})$.

24. DS 1639.

25. Yves Congar, Un peuple messianique: L'Eglise: sacrement du salut, salut et libération (Paris: Edition du Cerf, 1975), p. 31.

26. Karl Rahner, The Church and the Sacraments (New York: Herder and Herder, 1963); Edward Schillebeeckx, Christ, the Sacrament of the Encounter with God (Kansas City: Sheed Andrews and McMeel, 1963). See also Avery Dulles, Models of the Church (New York: Doubleday \& Co., 1974); Gustave, Martelet, 'De la sacramaentalité propre à l'Eglise,' Nouvelle revue théologique 95 (173), pp. 25-42; P. Smulders, 'L'Eglise sacrement du salut', in G. Barauna (ed.) L'Eglise de Vatican II, vol. 2 (Paris: Cerf, 1967), pp. 313-338; Jan Groot, 'The Church as Sacrament of the World', Concilium vol. 1, no. 4 (January 1968).

27. Catholicism (San Francisco: Ignatius Press, 1988), p. 76.

28. Lumen gentium, 8.

29. Karl Rahner, Studies in Modern Theology (London: Burns \& Oates, 1974), p. 201.

30. Dulles, Models, p. 74.

31. Rahner, Church and Sacraments, p. 22.

32. World Council of Churches, The Nature and Mission of the Church, Faith and Order Paper 198 (Geneva: World Council of Churches, 2005), p. 29.

33. Ibid.

34. Guiseppe Alberigo, 'Ecclesiology and Democracy: Convergences and Divergences', in J. Provost and K. Wolf (eds), The Tabu of Democracy within the Church, Concilium (\#5, 1992), p. 21.

35. Sacrosanctum Concilium, 2.

36. Ibid., 14. Pope Benedict XVI links active participation in the liturgy with active participation in the Church and also its mission in Sacramentum Charitas, 55.

37. See Paul Bradshaw, Liturgical Presidency in the Early Church, Grove Liturgical Study No.

36 (Bramcote: Grove Books, 1983), pp. 7-8: '[In the New Testament] ... no one was ordained or appointed to an office which consisted primarily of saying the Eucharistic prayer, but whoever said it did so as the natural expression of what they already were within the community'. Herré Legrand strongly emphasizes the link between pastoral leadership and liturgical presidency in "The Presidency of the Eucharist according to Ancient Tradition," in Living Bread, Saving Cup: Readings on the

Ecclesiology, Vol 7, No. 2 (May 2011): pg. 147-172. DOI. This article is @ Brill Academic Publishers and permission has been granted for this version to appear in e-Publications@Marquette. Brill Academic Publishers does not grant permission for this article to be further copied/distributed or hosted elsewhere without the express permission from Brill Academic Publishers. 
Eucharist, ed. Kevin Seasolz (Collegeville: Liturgical Press, 1987), pp. 196-221.

38. Lumen gentium, 15.

39. See Gaudium et Spes, 22.

40. Yves Congar, 'The Church: The People of God', Concilium 1 (1965), pp. 7$19,8$.

41. Lumen gentium, 14.

42. Ibid.

43. Ibid., 9.

44. Ibid., 11.

45. Ibid., 12.

46. Congar, p. 9, citing K Mörsdorf, 'Die Kirchengliedschaft im Lichte der kirchlichen Rechtsordnung', in Theologie und Seelsorge (1944), pp. 115f. See Yves Congar, "Moving Towards a Pilgrim Church," in Vatican II Revisited by Those Who Were There, ed. By Alberic Stacpoole (Minneapolis: Winston Press, 1986), pp. 129-152.

47. Ibid., 9.

48. Ibid., 11.

49. Believers in Christ have been born again not from a perishable but from an imperishable seed through the word of the living God (see 1 Peter 1: 23), not of flesh but of water and the Holy Spirit (see John 3: 556 ); and they have been finally set up as 'a chosen race, a royal priesthood, a holy nation, God's own people ... once no people but now God's people' (1 Peter 2: 9-10).

50. Lumen gentium, 20.

51. The Final Report, 'The Church, in the Word of God, Celebrates the Mysteries of Christ for the Salvation of the World' (National Catholic News Service), II, C, 1.

52. See Jean-Marie R. Tillard, L'Église locale: Ecclésiologie locale:

Ecclesiologie de communion et catholicité (Paris: Éditions du Cerf, 1995); Church of Churches: The Ecclesiology of Communion, trans. R. D. De Peaux (Collegeville: Liturgical Press, 1992); Dennis Doyle, Communion Ecclesiology (Maryknoll: Orbis Press, 2000); Susan K. Wood, 'The Church as Communion', in The Gift of the Church, ed. Peter Phan (Collegeville: Liturgical Press, 2000), pp. 159-176; Edward P. Hahnenberg, "The Mythical Body of Christ and Communion Ecclesiology: Historical Parallels," Irish Theological Quarterly 70: 3 (2005), pp. 3-30.

53. Lumen gentium 26.

54. Lumen gentium, 26.

55. Lumen gentium 23.

56. Lumen gentium 18.

Ecclesiology, Vol 7, No. 2 (May 2011): pg. 147-172. DOI. This article is @ Brill Academic Publishers and permission has been granted for this version to appear in e-Publications@Marquette. Brill Academic Publishers does not grant permission for this article to be further copied/distributed or hosted elsewhere without the express permission from Brill Academic Publishers. 
57. See Dennis M. Doyle, Communion Ecclesiology (New York: Orbis, 2000); J.-M. R. Tillard, Church of Churches: The Ecclesiology of Communion (Collegeville: Liturgical Press, 1992). For communion ecclesiology from a Lutheran perspective see Heinrich Holze (ed.), The Church as Communion (Geneva: Lutheran World Federation, 1997).

58. Pope John Paul II, Address to American bishops on September 16, 1987 in Origins 17:16 (October, 1, 1987): 258. Whereas Lumen gentium 8 states that the Church of Christ subsists in the Catholic Church, Pope Jonh Paul II asserts by analogy that all the elements of the Catholic Church are present in the particular or local church: 'The Catholic Church herself subsists in each particular Church, which can be truly complete only through effective communion in faith, sacraments and unity with the whole Body of Christ. Last November, in my letter to you during your meeting in Washington, I dealt at some length with this aspect of communion. At that time I wrote: "The very mystery of the Church impels us to recognize that the one, holy, Catholic and apostolic Church is present in each particular Church throughout the world. And since the Successor of Peter has been constituted for the whole Church as Pastor and as Vicar of Christ (Cfr. ibid. 22), all the particular Churches - precisely because they are Catholic, precisely because they embody in themselves the mystery of the universal Church - are called to live in communion with him."'

59. Lumen gentium, §23.

60. Lumen gentium, §23. In the homily for the ordination rite, the bishopelect is admonished to 'have a constant concern for all the churches and gladly come to aid and support of churches in need'.

61. See Susan Wood, 'The Sacramentality of Episcopal Consecration', Theological Studies 51 (1990), pp. 479-96.

62. Cyprian, Letter 66 (69), 8 to Florentius Pupianus, C. E. 254.

63. Lumen gentium, 18.

64. Lumen gentium, 8.

65. Lumen gentium, 23: in quibus and ex quibis una et unica ecclesia catholica exsistit. See Henri de Lubac, Les églises particuliéres dans I'Église universelle (Paris: Aubier Montaigne, 1971).

66. J. Komonchak, 'On the Priority of the Universal Church: Analysis and Questions', 12. (manuscript).

67. Lumen gentium, 12.

68. Ibid., 25.

69. D.S. 3074.

70. See, for example, Paul C. Empie, T. Austin Murphy, Joseph A. Burgess (eds.), Teaching Authority and Infallibility in the Church: Lutherans and Catholics in Dialogue VI (Minneapolis: Augsburg, 1978).

71. See Lumen gentium, 8.

Ecclesiology, Vol 7, No. 2 (May 2011): pg. 147-172. DOI. This article is @ Brill Academic Publishers and permission has been granted for this version to appear in e-Publications@Marquette. Brill Academic Publishers does not grant permission for this article to be further copied/distributed or hosted elsewhere without the express permission from Brill Academic Publishers. 